\title{
EIDdA
}

Revista Eletrônica de Estudos Integrados em Discurso e Argumentação

dx.doi.org/10.17648/eidea-16-2211

\section{A MIDIATIZAÇÃO CONTEMPORÂNEA DO POLÍTICO: OS DISCURSOS PRESIDENCIAIS NAS REDES SOCIAIS E A REAÇÃO DO CIDADÃO ARGENTINO}

\section{Ana Slimovich ${ }^{\mathrm{i}}$}

Resumo: $O$ objetivo deste artigo é investigar os discursos políticos que surgem nas redes sociais do presidente argentino Mauricio Macri e as formas de constituição de um movimento cidadão que é gerado na rejeição de sua gestão. Esta campanha, que chegou às redes sociais sob a hashtag \#ElFracasodeMacri, faz parte de um novo tipo de sociedade que Carlón (2015) define como uma sociedade hipermidiática contemporânea, e faz parte de uma nova fase de midiatização da política. Articularemos as conceituações da midiatização da política veroniana e europeia (COULDRY, 2014, HJARVARD, 2014, MAZZOLENI e SCHULZ, 1999, STROMBACK, 2008, VERÓN, 1983, 1986, 1998 [1995], 2001, 2013), com o ferramental do dispositivo analítico da circulação hipermidiática contemporânea (CARLÓN, 2015), que toma como ponto de partida a sócio-semiótica como campo de abordagem da dimensão significativa dos fenômenos sociais (VERÓN, 1987).

Palavras-chave: Midiatização. Política. Redes sociais. Governo.

\begin{abstract}
The objective of this work is to investigate the political discourses that appear in the social networks of the Argentine President, Mauricio Macri, and the forms of constitution of a citizen movement that is generated in the rejection of his government. This campaign, which reached social networks under the hashtag \#ElFracasodeMacri, is part of a new type of society that Carlón (2015) defines as hypermedia contemporary, and is part of a new phase of mediatization of politics. We will articulate the conceptualizations Veronian and European of the mediatization of the politics (COULDRY, 2014, HJARVARD, 2014, MAZZOLENI and SCHULZ, 1999, STROMBACK, 2008, VERÓN, 1983,1986, 1998 [1995], 2001, 2013), with the methodology of the analytical device of contemporary hypermedia circulation (CARLÓN, 2015), which takes as a starting point socio-semiotics as a field of approach to the significant dimension of social phenomena (VERÓN, 1987).
\end{abstract}

Keywords: Mediatization. Politics. Social media. Government.

\footnotetext{
'Pesquisadora do Instituto de Investigações Gino Germani da Universidade de Buenos Aires (IGGUBA) e do Conselho Nacional de Investigações Científicas e Técnicas (CONICET), Argentina. E-mail: aslimovich@gmail.com.
} 
EID\&A - Revista Eletrônica de Estudos Integrados em Discurso e Argumentação, Ilhéus, n. 16 esp.“"Discurso e argumentação na política latino-americana, set.2018.

\section{Introdução}

A política contemporânea está atravessada por processos de interação com as mídias de comunicação em massa e com as mídias internetizadas, gerando novas formas de discursos políticos e novos modos de fazer campanha eleitoral. O processo de midiatização do político sofreu mudanças com as mídias de comunicação em massa e, em particular, sofreu aceleração no último quarto do século XX (VERÓN, 2001). Partindo da perspectiva de Eliseo Verón, na primeira fase da sociedade das mídias de comunicação em massa, na "sociedade midiática" as práticas políticas são influenciadas pelos meios de comunicação que geram uma estratégia de representação e se posicionam como "espelho" de um "exterior real". Entretanto, na "sociedade midiatizada" posterior, conta com uma hegemonia das mídias em massa, especialmente a televisão, capaz de construir a realidade. As práticas políticas na era das mídias em massa se estruturam em função das lógicas das mídias tradicionais e nocauteiam o limite entre o real e a suas representações.

Partindo dessa perspectiva, Carlón (2015) postula que no momento contemporâneo direcionamos nossa voz a uma "sociedade hipermidiatizada". Nela, a circulação discursiva se transformou devido à crise da hegemonia das mídias em massa, o surgimento de um novo sistema midiático (as mídias internetizadas) e as relações intersistêmicas, entre o sistema das mídias em massa e o sistema das novas mídias.

A fase contemporânea da midiatização implica em um processo de inserção dos discursos políticos nas redes sociais: um processo que supõe a consolidação e acentuação dos processos de personalização e personalismo do mundo da política, assim como novas interfaces entre os discursos informativos-midiáticos e as suas lógicas, os líderes políticos, os discursos e as reações civis (SLIMOVICH, 2016a). Como são os discursos políticos contemporâneos que são transmitidos pelas redes sociais do presidente argentino e estão em interação com as mídias de comunicação em massa? Como se configuram os movimentos dos cidadãos em repúdio ao governo argentino, em relação às mídias tradicionais com as redes sociais? Como se afirmam os coletivos políticos argentinos nas redes sociais e como se

\footnotetext{
1 "El living y sus dobles: arquitecturas de la pantalla chica", de Eliseo Verón, foi publicado originalmente em francês em 1984 ("Le séjour et ses doubles: architectures du petit écran") e em 2001 foi incluído como um capítulo do livro El cuerpo de las imágenes.
} 
EID\&A - Revista Eletrônica de Estudos Integrados em Discurso e Argumentação, Ilhéus, n. 16 esp.“Discurso e argumentação na política latino-americana, set.2018.

estabelecem as relações com as instituições políticas e midiáticas? Essas são questões que orientam este trabalho.

Neste artigo focalizaremos especificamente a indagação da caracterização dos discursos políticos que surgem nas redes sociais do presidente argentino Mauricio Macri e os modos de constituição de um movimento civil que se originou nas redes sociais em repúdio aos 500 dias de sua gestão: \#elfracasodeMacri.

Dado que o objetivo deste trabalho vincula-se a indagar a circulação dos discursos políticos contemporâneos e os movimentos sócio-políticos integrados às redes sociais, articularemos a análise da midiatização do político (COULDRY, 2014; HJARVARD, 2008, 2014; MAZZOLENI e SCHULTZ, 1999; STROMBACK, 2008; VERÓN, 1983, 1986, 1998[1995], 2001), com a ferramenta metodológica do dispositivo analítico da circulação hipermidiática contemporânea (CARLÓN, 2015, 2016a, 2016b; CARLÓN, FRATICELLI, SLIMOVICH e ROYNER, $2017^{2}$ ), que dá conta de uma circulação mais complexa entre os meios de comunicação em massa e as novas mídias e parte dos princípios da sócio semiótica como campo de abordagem da mesma dimensão significante dos fenômenos sociais (VERÓN, 1987). Desta forma, faremos uma aproximação a um modo de estudo dos movimentos sociais, interligando esses conceitos com a abordagem da comunicação de Castells (2009, 2012).

O trabalho organiza-se do seguinte modo: em um primeiro momento detalharemos os conceitos da midiatização da política pela corrente veroriana e europeia. Num segundo momento, focaremos nas indagações dos aspectos da midiatização da política contemporânea e revelaremos os aspectos mais aparentes do dispositivo analítico da circulação hipermidiática contemporânea. Em seguida, descreveremos as características específicas do discurso de Mauricio Macri no Facebook e Twitter. E num quarto momento, compararemos as produções discursivas e as circulações do movimento de repúdio à sua gestão aglutinadas na campanha \#ElfracasodeMacri. E por fim, esboçaremos as considerações finais.

\footnotetext{
¿ O modelo analítico da circulação hipermidiática contemporânea se desenvolve na matéria de "Semiótica das redes", cátedra Mario Carlón, do Departamento de Ciência de Comunicação da Faculdade de Ciência Sociais da Universidade de Buenos Aires - ver TP.Doc (CARLÓN, FRATICELLI, SLIMOVICH e ROVNER, 2017). Disponível em: www.semioticaderedes-carlon.com
} 
EID\&A - Revista Eletrônica de Estudos Integrados em Discurso e Argumentação, Ilhéus, n. 16 esp.“Discurso e argumentação na política latino-americana, set.2018.

\section{Midiatização da política na visão veroniana e europeia}

Para Verón (2001 [1984]) o processo de midiatização fez com que a política já não tivesse mais acesso aos meios para ser representada perante seus cidadãos, mas sim que se pensa a si mesma a partir da lógica das mídias. Deste modo, na democracia audiovisual avançada, "uma campanha eleitoral não é um processo alheio, como tal, às mídias (forma parte, digamos, do campo do político) e que as mídias se limitariam a refletir, a re-produzir, melhor ou pior: uma campanha eleitoral é cada vez mais pensada, organizada, administrada, em função da televisão" (p. 15). Assim, na sociedade midiatizada "o funcionamento das instituições, das práticas, dos conflitos, da cultura começa a estruturar-se na relação direta com a existência das mídias" (p.15). Os fenômenos da sociedade adquirem formas específicas em virtude da existência das mídias. Em outras palavras, as mídias não reproduzem um real externo, mas são produtoras de sentido.

O autor de La Semiosis Social (VERÓN, 2013) defende que as lógicas das mídias de comunicação em massa tem influência nos processos sociais. A midiatização opera, nessa perspectiva, com mecanismos diferentes segundo o aspeto social atingido, alterando o vínculo dos sujeitos com o espaço-tempo social; e produzindo também efeitos particulares sobre os públicos. Em sua obra, o autor sublinha que a expansão das mídias em massa supõe uma interface do informativo e do político. Nesse sentido, alude-se que a emergência do político no espaço público implicou historicamente a intermediação dos jormais e dos discursos midiáticos. Desse modo, nas sociedades midiatizadas a estrutura da campanha eleitoral se realiza em função das lógicas do televisivo informativo. Por outro lado, as redes sociais supõem um processo de desintermidiação: a interface informativa política se desintegra nos perfis das redes sociais dos políticos e aí se configura o vínculo entre o líder político e o cidadão internauta (SLIMOVICH, 2012, 2016a), ao invés do líder político-telespectador cidadão-jornalista da televisão informativa. Sem embargo, é possível destacar que as redes sociais dos discursos políticos convivem com outras discursividades: as provenientes das mídias tradicionais, as de outros políticos, as instituicionais e as dos internautas: os conteúdos gerados pelos usuários ${ }^{3}$.

\footnotetext{
${ }^{3}$ Em outro trabalho (SLIMOVICH, 2016a, 2016b) detalhamos os tipos de interfaces políticoinformativas que se produzem nas apropriações de lógicas e conteúdos do televisivo e do informativo por parte dos líderes políticos argentinos no período de campanha eleitoral em suas contas de Facebook e Twitter.
} 
EID\&A - Revista Eletrônica de Estudos Integrados em Discurso e Argumentação, Ilhéus, n. 16 esp.“"Discurso e argumentação na política latino-americana, set.2018.

O semioticista argentino afirma que a midiatização da política implicou um processo de complexização do discurso político, uma vez que ao registro simbólico - dominante na imprensa gráfica - se adicionaram a ordem icônica e a ordem dos indícios midiatizados. Ou seja, por um lado, a palavra não se anula; e, por outro lado, o corpo político - que por definição é um corpo social - não compõe a "linguagem"; é um componente estrutural da democracia audiovisual. A midiatização do icônico e do indício permite incorporar, em um nível coletivo, operações que anteriormente apenas eram possíveis no contexto imediato da semiose interindividual. Em outras palavras, existem operações de interação face a face que vão além das mídias de comunicação em massa. Deste modo, Verón (2013) se distancia das teorias apocalípticas que supõem um empobrecimento do discurso político ao produzir sua midiatização (SLIMOVICH, 2016a) e $^{4}$ atribuem a banalização e o fim de seus componentes controversos a esse processo. De fato, para interrogarmos os modos de inscrição do cidadão público nas redes sociais, os modos de relação com discursos de Macri nos espaços digitais e a interação com as mídias em massa, nos deteremos em como se formam os coletivos políticos.

Na descrição da evolução histórica do processo de midiatização, Verón (1998 [1995]) informa que até a década de 80 do século XX coexistiam duas esferas: de um lado, a esfera política como espaço de configuração dos coletivos identitários ${ }^{5}$ associados a uma gestão de longo prazo; e de outro, a esfera midiática, espaço de configuração dos coletivos associados ao curto prazo (mais circunstancial e vinculado ao consumo). A televisão se constitui como o principal suporte da midiatização do político, gerando a crise de legitimidade do político, e concomitantemente fortalecendo o papel das mídias sociais tradicionais.

É preciso pontuar que embora os coletivos gerados pelas mídias sejam provenientes de uma cena de consumo específica momentânea e constituam um determinado público - eles são coletivos de comunicação -; e aqueles que

\footnotetext{
4 Em outro trabalho (SLIMOVICH, 2016a) observamos a existência de conceitos teóricos vinculados a videopolítica - que supõe um empobrecimento do discurso político ao mediatizar-se, especialmente em sua imbricação com a televisão. Provamos que a medida que se avança a mediatização do político existe uma idealização que se apoia na comparação com a etapa anterior. Ao se inserir nas redes sociais, o discurso político produz uma idealização do momento anterior e argumenta-se um empobrecimento do discurso político ao digitalizar-se em sua comparação paradoxal com o discurso televisivo.

${ }^{5}$ Seguiremos o conceito de coletivo desenvolvido por Verón em Semiosis Social II: "um coletivo é uma classe de atores socais que são reconhecidos como tal por uma sociedade" (VERÓN, 2013: p. 421) e que pode conjugar-se por meio de um interesse em comum e se desfazer, uma vez que este se dissolve.
} 
EID\&A - Revista Eletrônica de Estudos Integrados em Discurso e Argumentação, Ilhéus, n. 16 esp.“"Discurso e argumentação na política latino-americana, set.2018.

são gerados pelos políticos são coletivos formais, são postulados, provêm de um sistema político e constituem cidadãos; a tese de Verón (1995, 2011, 2013) é que ambos começam a se misturar. Nesse sentido que o semioticista argentino sustenta a primazia dos coletivos identitários de curto prazo (SLIMOVICH, 2016a; p. 73).

Assim, na sociedade midiática, os coletivos gerados pelas mídias são diferentes das instituições políticas. Nas sociedades midiatizadas, plenamente hegemônicas das mídias em massa, os coletivos gerados pelas mídias e os das instituições políticas tendem a misturar-se. Nas sociedades atuais, as hipermidiáticas, atravessadas por relações intermidiáticas e intersistêmicas, surgem coletivos sócio-políticos nas redes sociais (CÁRLON, 2015), como o que indagaremos nesta pesquisa: o coletivo articulado ao protesto pelo rumo do governo de Macri em abril de 2017.

\section{Midiatização do político a partir da visão europeia}

Outro antecedente na midiatização do político está vinculado à "corrente europeia de estudos de midiatização", uma perspectiva teórica que surge no final do século XX e que estuda o processo de influência dos meios de comunicação em outros campos. É possível determinar três linhas de investigação e pontos em comum com o conceito da midiatização do político veroniana que já esboçamos anteriormente.

A primeira linha considera a midiatização como uma característica do contemporâneo das sociedades ocidentais e, portanto, é vista como um metaprocesso, relacionado com outras transformações sociais como a "globalização" e a “individualização" (COULDRY, 2014; HJARVARD, 2008; KRIESI et al 2013; MARCINKOWSKI, 2014). Um dos autores mais citados, Hjarvard (2014), considera, em conformidade com Verón, que há uma estruturação das práticas sociais em interação contínua com o funcionamento midiático. Todavia, se distanciam do ponto de vista histórico: para o dinamarquês trata-se de uma característica da época; e para o semioticista argentino é parte da evolução da sociedade. Por outro lado, o ponto de vista de Hjarvard é a partir do neo-institucionalismo, diferente do ponto de vista do semioticista argentino.

Entretanto, há uma segunda linha de investigação: os teóricos da democracia pós-moderna. Trata-se de uma corrente que engloba autores ingleses e holandeses, que dividem o processo de inserção na política nas mídias em duas dimensões. De um lado a "midiatização" que veicula a relação 
EID\&A - Revista Eletrônica de Estudos Integrados em Discurso e Argumentação, Ilhéus, n. 16 esp.“"Discurso e argumentação na política latino-americana, set.2018.

entre as elites políticas e midiáticas com os cidadãos (BRANTS e VOLMER, 2011). Afirmamos que tal distinção, embora pudesse funcionar para analisar a inserção do político no televisivo, resulta ao final problemática para analisar o momento contemporâneo, dado o fato que os discursos políticos emergem também das redes sociais.

Por fim, há uma terceira corrente que considera a midiatização em relação ao processo de constituição histórica dos meios de comunicação em massa e seus modos de influência, principalmente no mundo político democrático ocidental (MAZZOLENI e SCHULTZ, 1999; STRÖMBÄCK, 2008). De acordo com M. Fernández (2014) a midiatização da vida política, "considerada do ponto de vista da constituição do campo problemático, é, na verdade, um antecedente" (p. 192) do campo da midiatização e não uma variação. Assim como Verón, os autores europeus que se centram na midiatização do político também consideram uma relação intrínseca com o informativo. Um de seus referentes principais, Strömbäck (2008), propõe que existem quatro dimensões no processo de inserção da política nas mídias.

A primeira dimensão mostra como as mídias se tornam uma fonte de informação política, uma vez que se apresentam como um laço de interação entre os cidadãos e as instituições políticas. Assim, esta primeira dimensão contém a mediação. De fato, focaliza-se o rol de intermediários das mídias tradicionais: as mídias [médios] mediam "entre a cidadania, por um lado, e as instituições envolvidas com o governo, as eleições e a formação de opinião, por outro" [tradução da autora] (ESSER, 2013, p. 157). A segunda está vinculada à autonomia que obtiveram as mídias políticas institucionais; e, consequentemente, seu modo de funcionamento ligado mais à lógica midiática, que a qualquer lógica política. Nesta segunda fase, as mídias possuem mais autonomia que na primeira, gerando assim, a profissionalização do jornalista.

A terceira dimensão está associada ao grau de conteúdo midiático que é governado pela lógica midiática ou política. Coloca-se em questão o aumento da autonomia midiática em relação à segunda fase. As mídias são, nessa fase, de tal importância que "nenhum ator social que demande uma interação social com o público ou exerça influência na opinião pública pode ignorar as mídias e assumir o custo de não se adaptar à lógica midiática" [tradução da autora] (STÖMBÄCK, 2008, p. 238). Definitivamente, como produto da midiatização, os líderes políticos, seus discursos e suas ações, nesta fase, se 
EID\&A - Revista Eletrônica de Estudos Integrados em Discurso e Argumentação, Ilhéus, n. 16 esp.“Discurso e argumentação na política latino-americana, set.2018.

adaptam à lógica midiática (aos critérios de noticiabilidade e aos gêneros dos discursos informativos). Trata-se, por exemplo, da ênfase que os políticos dão ao conflito e à personalização em suas declarações televisivas concedidas aos jornalistas.

A quarta dimensão focaliza os atores políticos e o grau em que são governados pela lógica midiática ou pela lógica política. "Os políticos e outros atores sociais não somente adaptam-se à lógica midiática" [...] como também a internalizam [tradução da autora] (HJARVARD, 2008 - itálico pelos autores). Isto implica que as regras e convenções midiáticas passam a formar parte das ações políticas, inclusive o desenvolvimento das ideias. O processo de "absorção" dos hábitos e convenções da mídia por parte dos políticos leva à ação: por exemplo, a organização de pseudo-eventos para alcançar repercussão.?.

Vale ressaltar que esse acréscimo na divisão proposta por Strömbäck entre quais conteúdos provêm do midiático e quais provêm da política tem seu excesso em alguns casos. Existem processos, como, por exemplo, a concentração de uma figura política em detrimento do partido, que ocorrem simultaneamente nas práticas dos partidos políticos e nas representações da política nas mídias televisivas. Já definimos esses processos em outro trabalho (SLIMOVICH, 2016) como personalismo e personalização na midiatização da política. Entretanto, embora acreditemos que as fases do modelo não possam ser avaliadas autonomamente e não correspondam linearmente aos processos históricos, achamos frutífero - para nossa análise dos discursos políticos contemporâneos nas redes sociais - retomar dessa questão a dicotomia entre as duas últimas dimensões da transformação da política - a adaptação dos atores políticos à lógica midiática (terceira dimensão) e a adoção e internalização da institucionalidade midiática (quarta dimensão). Voltaremos a essas duas dimensões da midiatização do político para nos questionarmos sobre os discursos políticos contemporâneos.

Portanto, se as fases propostas não podem avaliar de maneira autônoma e não corresponde linearmente aos processos históricos, parece-nos frutífero - para nossa análise dos discursos políticos contemporâneos nas redes sociais

\footnotetext{
${ }^{6}$ O verbo utilizado por Strömbäck (2008) para explicar a relação entre os políticos e as regras mediáticas na terceira fase é "adaptar" ("to adapt") e na quarta fase usa "adoptar" ("to adopt").

${ }^{7}$ Esse processo também pode ser denominado como auto midiatização (ESSER, 2013; STRÖMBÄCK e ESSER, 2014), midiatização de segunda ordem ou midiatização reflexiva (MARCINKOWSKY, 2014); em oposição à midiatização de primeira ordem ou midiatização direta (Os políticos são representados pelas mídias em massa através da cobertura das notícias).
} 
EID\&A - Revista Eletrônica de Estudos Integrados em Discurso e Argumentação, Ilhéus, n. 16 esp.“Discurso e argumentação na política latino-americana, set.2018.

- retomar a dicotomia instaurada nas duas últimas dimensões da transformação política - a adaptação dos atores políticos a lógica midiática (terceira dimensão) e a adoção e internalização do institucional midiático (quarta dimensão). Retornaremos a essas duas dimensões da mediatização para nos interrogarmos acerca dos discursos políticos contemporâneos.

\section{Política contemporânea hipermidiatizada}

A diferença da era das mídias em massa com a sociedade hipermidiatizada contemporânea é que há novos modos de circulação dos discursos.

Os internautas têm à disposição, nas redes sociais, meios reais de comunicação e, portanto, seus próprios espaços de intervenção na vida social. São nesses espaços, desprovido de neutralidade, que eles agem como sujeitos ativos em multiplas operações: opinam, compartilham e se apropriam de conteúdos que os interessam (originados das mídias em massa, da história da arte, da fotografia, etc.) (CARLÓN, 2016c).

Desde o final do século XX a circulação discursiva teve "uma direção descendente", pois se produziu, a partir das grandes instituições e dos meios de comunicação em massa, receptores em massa. Porém, na contemporaniedade surgem coletivos de comunicação num processo ascendente (CARLÓN, 2015). Em resumo, trata-se de internautas desconhecidos que com seus discursos nas redes sociais geram coletivos de comunicação que ganham força nas mídias em massa.

Os movimentos sócio-políticos que surgem nas redes sociais geram repercussões nas mídias tradicionais. Segundo a teoria de Castells (2009, 2012), esses movimentos tendem a ocupar o espaço urbano, advém em situações de crise política, econômica e social e tendem a ser desencadeados por um acontecimento político específico ou por uma deteriorização de uma situação. Por exemplo, em 2011, ocorreu a primavera árabe, o movimento dos indignados na Espanha e o Occupy Wall Street nos Estados Unidos e países europeus. Mais recentemente, na Argentina, em 2015, ocorreu o "panelaço" [cacerolero] contra o governo de Cristina Fernández de Kirchner e, em 2016 e 2017, contra o aumento das tarifas dos serviços públicos, associados com um grupo político que visava à renúncia do ministro macrista de Energia e Minérios (SLIMOVICH, 2017a). Esses movimentos são constituídos por redes de mensagens autônomas e horizontais. Isto é, as instituições históricas que 
EID\&A - Revista Eletrônica de Estudos Integrados em Discurso e Argumentação, Ilhéus, n. 16 esp."Discurso e argumentação na política latino-americana, set.2018.

produziam essas mensagens na era de plena hegemonia das mídias em massa, começam a ter dificuldades para controlar esses novos coletivos políticos, pois "o poder na sociedade em rede é o poder da comunicação" (CASTELLS, 2009: p.85). Entretanto, desenvolveremos, a seguir, como alguns desses movimentos, como o caso de \#ElfracasodeMacri tem ancoragem e conexões com a militância tradicional e as forças políticas. Há outros casos de movimentos como o \#NiUnaMenos (SLIMOVICH e FRATICELLI, 2016) gerados por internautas desconhecidos nas redes sociais e em um dado momento do desenvolvimento histórico desse movimento, ocorre a ocupação do espaço urbano pelos sujeitos sócio-políticos constituídos em um coletivo.

Por que um enunciador desconhecido pode começar na contemporaneidade um movimento sócio-político? É possível fazê-lo na condição de sujeito midiático. Isto é, "devido ao fato de dispor de mídias de comunicação individuais que the permitem a publicação em redes sociais distintas" (CARLÓN, 2016b: p. 23). Também é possível dizer que sua enunciação não é de ordem do individual: é "social ou supraindividual" (Ibidem). E nesse sentido, no caso de reação de apoio ao governo de Mauricio Macri, o movimento encabeçado pela hashtag \#1aporlaDemocracia, os enunciadores que emergem das redes sociais formam um coletivo que repudia as críticas ao governo e a greve e, assim, se mobilizam para defendê-lo. Por outro lado, no movimento \#ElfracasodeMacri trata-se de um grupo de internautas públicos e figuras políticas que convocam o veto ao governo de Macri e logo se associam a coletivos políticos dos internautas amadores.

Os meios de comunicação em massa continuam configurando algumas das histórias e argumentações políticas que estão no cerne da vida social; entretanto, se associaram às vozes desintermidiadas dos próprios políticos e as vozes dos cidadãos no espaço público que se alarga com as mídias internetizadas (SLIMOVICH, 2012). Então, podemos dizer que a política contemporânea implica em um processo de inserção do político nas redes sociais se enquadrando em uma fase da midiatização atravessada pelas interações midiáticas e, também, entre o sistema de mídias em massa e as "novas mídias".

Devido ao aumento dos enunciadores políticos e dos discursos políticos nas redes sociais produziu-se um alargamento do espaço público. Evidenciando que o público replicante da internet não é apenas constituído por militantes e membros de partidos políticos, mas também se ampliou. "Incorporou-se na 
EID\&A - Revista Eletrônica de Estudos Integrados em Discurso e Argumentação, Ilhéus, n. 16 esp.“"Discurso e argumentação na política latino-americana, set.2018.

esfera pública cidadãos que não tinham um papel ativo nas campanhas políticas que se desenvolviam unicamente nos meios de comunicação em massa" (SLIMOVICH, 2015: p.15).

Sustentamos que a política contemporânea está atravessada por novas formas de participação que deram lugar a uma "democracia contínua" (CHERESKY, 2015). Acreditamos que cada decisão governamental pode desencadear uma reação dos cidadãos. Esses movimentos estabelecem uma relação diferente com as instituições políticas e midiáticas. Portanto, surgem novos movimentos civis - muitas vezes ligados ao repúdio e ao veto - como o que surgiu com o desaparecimento de 43 estudantes de Ayotzinapa, que se articulou nas redes sociais visando um esclarecimento e justiça e em reação as intervenções governamentais (SLIMOVICH e TONATIUH LAY, 2017). A seguir, desenvolveremos o caso do movimento civil em repúdio ao governo do presidente argentino em abril de 2017.

\section{Discurso político de Macri nas redes sociais}

Em trabalhos anteriores (SLIMOVICH, 2012, 2016a, 2016b) se fez referências às discursividades dos políticos argentinos no Twitter e Facebook das primeiras eleições nas redes sociais - indicando que elas tendem a configurar micro argumentações lógicas e passionais, que são pildorizadas ${ }^{8} \mathrm{e}$ multimidiáticas. São argumentações que tendem a constituir-se na interrelação das diferentes mídias: tanto aquelas em massa como as redes sociais. Nesse sentido, uma das questões que nos fazemos neste trabalho é se os discursos políticos dos civis, provenientes das redes sociais e em reação a uma decisão governamental, também se constroem nesse tipo de argumentação.

Numa outra perspectiva, como já falamos anteriormente, tanto na teoria da midiatização política veroniana quanto na corrente europeia, o discurso político quando aparece nas mídias em massa está em interface com o discurso informativo. Provamos que também os discursos políticos contemporâneos, que se encontram nas redes sociais e nas mídias em massa, constituem-se em interface com o informativo televisivo e com as lógicas das mídias em massa, entretanto se trata de outro tipo de interface (SLIMOVICH, 2012, 2016a, 2016b). De fato, os líderes políticos nos espaços digitais desintermidiados dos jornalistas, possuindo suas contas oficiais nas redes

\footnotetext{
${ }^{8}$ No original: pildorizadas. Uma expressão que carrega o senso de "encontrar condensado".
} 
EID\&A - Revista Eletrônica de Estudos Integrados em Discurso e Argumentação, Ilhéus, n. 16 esp.“"Discurso e argumentação na política latino-americana, set.2018.

sociais, tendem a se apropriarem de conteúdos da televisão informativa e a emularem lógicas e operações dos noticiários, dos programas políticos de opinião ou da imprensa gráfica. Imitam modos e operações que derivam da midiatização política da televisão, da imprensa gráfica e rádio, como, por exemplo, a utilização de informações breves em suas próprias publicações. Da mesma forma, tendem a reproduzir, apresentar e reapresentar discursos audiovisuais não televisivos e televisivos. Como aparecem nas redes sociais de Macri essas operações e processos próprios da política contemporânea? E nos grupos de internautas de oposição a seu governo?

O Partido Propuesta Republicana (PRO) foi fundado em torno da figura de Mauricio Macri em 2002 e reuniu gestores da direita argentina, dos partidos majoritários (o peronismo e o radicalismo) e também da sociedade civil (empresas, ONG, e Think Thank) (VOMMARO e MORRESI, 2014).

Desde o início, as aparições públicas do PRO foram muito cuidadosas, tanto para a difusão para as mídias como para os micropúblicos e para reuniões partidárias (VOMMARO, MORRESI e BELLOTI, 2015). Além disso, o partido caracterizou-se pelo uso da publicidade e das redes sociais. No final do século XX, torna-se habitual na Argentina que os políticos recorram, em tempos de campanha eleitoral, aos especialistas em opinião pública e personalidades ligadas à publicidade. Desta forma, o discurso do PRO foi marcado especialmente pelos discursos de marketing e seu líder de estratégia, Jaime Durán Barba, foi protagonista nos principais momentos eleitorais.

Nas redes sociais de Macri é possivel notar, desde o início da sua incursão digital, desde o momento inicial de sua pré-candidatura à presidência de 2010 - então, cancelada - um enquadramento discusivo que mistura o público e os componentes de ordem biográfica, mantidos até 2017. Há uma teatralização da vida privada: uma cena da subjetividade postada em seu mural do Facebook assim como em sua timeline do Twitter, um processo que destaca seu papel como um homem comum, de acordo com os processos de personalização e personalismo da política contemporânea: evidencia seu papel como integrante de uma família, esposo, pai. Esses processos se combinam com operações de inter-relação midiática.

Anteoriormente à sua campanha presidencial de 2015, no mural do Facebook há evidências de uma mudança do enquadramento discursivo que combina a vida privada e íntima do candidato com a vida pública, característica recorrente dos períodos anteriores. E "se registra uma tendência para 
EID\&A - Revista Eletrônica de Estudos Integrados em Discurso e Argumentação, Ilhéus, n. 16 esp."Discurso e argumentação na política latino-americana, set.2018.

interpelações dos seguidores macristas por métodos que apelam para as emoções, como os vídeos e audios de Antonia Macri, assim como fotos que pertencem ao álbum de família" (SLIMOVICH, 2017b). No entanto, há breves argumentações relacionadas ao passional e ao racional que se combinam ao articular as diferentes redes sociais, a imprensa gráfica e a televisão, um exemplo é a apropriação que Macri faz, em seu mural do Facebook, de uma entrevista televisionada concedida a um candidato de seu partido ou, na timeline do Twitter, de uma nota da imprensa gráfica.

Desse modo, há uma operação de articulação entre Facebook, a televisão e o espaço privado dos cidadãos. Uma das estratégias de campanha de Macri em 2015 ficou conhecida como "timbreo" e continua na etapa atual de sua gestão presidencial. Esta atividade consiste em bater à casa de cidadãos desconhecidos de todo o país, para conversar pessoalmente com eles, dentro de seu lar, filmando o encontro. Concomitantemente, difundiramse spots publicitários de televisão que continham fragmentos dessas visitas. Por sua vez, em seu mural do Facebook se produziu um processo de apropriação do spot publicitário, com as palavras do líder político, que relata o encontro em primeira pessoa. A apropriação do televisivo e a enunciação em primeira pessoa conjugam, então, uma história política convergente ancorada na vizinhança.

Concluindo, na pré-candidatura de 2010 e 2011, na candidatura de 2015 e também na gestão presidencial de 2016 e 2017 registra-se, nas redes sociais de Macri, um enquadramento nas produções discursivas que combina o público e o privado, partes de sua vida íntima assim como do cidadão, operações de apropriações da televisão e operações argumentativas. Como são os discursos políticos nas redes sociais dos opositores ao seu governo? As operações de inter-relação midiática se fazem presentes nos discursos políticos dos internautas opositores ao Macrismo? Como se configura o grupo político da oposição nas redes? No próximo tópico, avançaremos a essas modos de configuração dos coletivos político de oposição ao macrismo nas redes. Como já adiantamos, demonstraremos com o caso \#ElfracasodeMacri. 
EID\&A - Revista Eletrônica de Estudos Integrados em Discurso e Argumentação, Ilhéus, n. 16 esp.“Discurso e argumentação na política latino-americana, set.2018.

\section{El fracaso de Macri ${ }^{9}$}

A campanha \#ElfracasodeMacri surge no Twitter em 23 de abril de 2017, exatamente quando a presidência de Mauricio Macri chegava ao $500^{\circ}$ dia. Simultaneamente surgem tweets com essa hashtag das contas dos enunciadores descritos como enunciadores broadcast (CARLÓN, 2016): Mariano Recalde, Wado de Pedro, Adrés Larroque, Verónica Magario. O repúdio ao governo Macrista é ressaltado por operações comparativas entre a campanha e a gestão. Por exemplo, a superintendente de La Matanza na sua conta do Twitter, junto com a hashtag, compartilha um vídeo no qual cita frases do presidente no período anterior à campanha eleitoral, pronunciadas em programas televisivos - Telenoche, Intratables - no debate dos candidatos. Então, é possível compará-las por meio de placas escritas, com os dados da situação econômica atual ${ }^{10}$. Outro exemplo é a publicação de Mariano Recalde no Twitter que se opõe a uma citação da campanha de Macri, dita na televisão, em relação a sua intenção de diminuir a pobreza com surgimento dos novos pobres em sua gestão (figura 1). Assim, os líderes políticos por meio de suas contas no Facebook e Twitter colocam em cena o "arquivo televisivo" do presidente num plano paralelo às operações metadiscursivas que acontecem a partir da década de 80-90 na Argentina nos programas metatelevisivos (CARLÓN, 2006), como PNP, TVR ou Indomables. Bem como fazia Macri que gerava operações de apropriação de conteúdo dos meios de comunicação em massa no seu mural do Facebook e na sua Timeline do Twitter com o objetivo de difundir informação presidencial e de exibir o seu privado como cidadão; os líderes em oposição a Macri realizam nas suas redes sociais uma operação de apropriação das lógicas do metatelevesivo como fundamental denúncia política da gestão macrista.

\footnotetext{
${ }^{9}$ As produções discursivas dos internautas com a hashtag \#elfracasodeMacri foram analisadas durante 2017, sob o dispositivo analítico da circulação hipermidiática (CARLÓN, 2014, 2015, 2016B, CARLÓN et al, 2016) no comitê 21 da matéria Semiótica das Redes, presidente Mário Carlón, Departamento de Ciências da Comunicação da Faculdade de Ciências Social de Univerdade de Buenos Aires. O grupo que trabalhou esse tema é composto pelos alunos e alunas: Bargalló Castagnino, Delgado, Nicollier, Pereyra, Sanz, Schtivelband e Ventura.

${ }^{10}$ Disponível em https://twitter.com/magariovero/status/856294556341592064
} 
EID\&A - Revista Eletrônica de Estudos Integrados em Discurso e Argumentação, Ilhéus, n. 16 esp.“Discurso e argumentação na política latino-americana, set.2018.

Figura 1

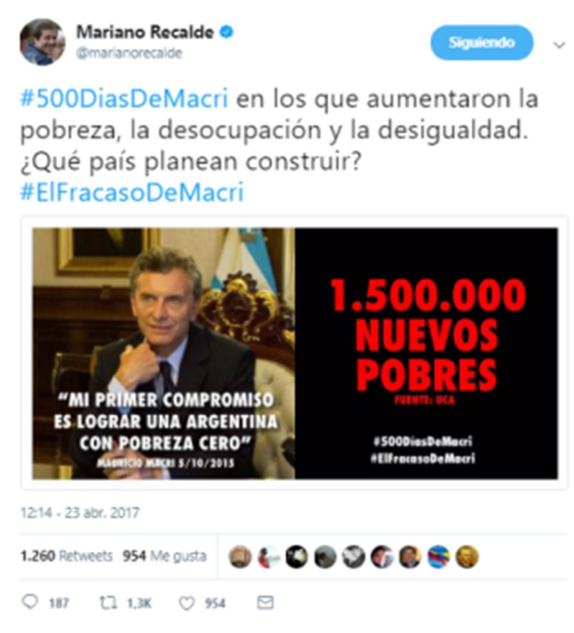

Essas novas interfaces entre o midiático e o político que se articulam com as redes sociais e que aparecem nas contas dos políticos se enquadram num procedimento específico da quarta fase da midiatização do político, a esteira de Strömbäck (2014), que propõe que se tratam de operações de adoção das lógicas midiáticas por parte dos atores políticos. Num plano paralelo, está a presença de uma estruturação política em função do midiático, característica da sociedade midiatizada, de acordo com Verón. E, além disso, a diferença da era das mídias em massa, no caso desta operação está incorporada ao sistema midiático das redes sociais, nos espaços digitais vinculados aos líderes políticos com a cidadania desintermidiados da figura do jornalista. Semelhantemente, como se pode perceber, os políticos voltam a introduzir no espaço público as lógicas e os conteúdos informativos midiáticos.

Todavia, colocar em cena a contradição entre a promessa de Macri como candidato presidencial e a sua gestão por meio de entrevistas e intervenções televisivas durante sua campanha é uma operação produtora de sentido que não só trouxe força aos líderes de oposição, como também fez os internautas desconhecidos se somarem a essa campanha. Os enunciadores, ao se apropriarem dos fragmentos de televisão do período de campanha presidencial em 2015 na forma de screenshot [capturas], com efeito, fizeram intervenção com as frases de promessas e adicionaram a referência temática à situação atual do país sob sua presidência (figura 2). 
EID\&A - Revista Eletrônica de Estudos Integrados em Discurso e Argumentação, Ilhéus, n. 16 esp."Discurso e argumentação na política latino-americana, set.2018.

\section{Figura 2}

\& Seguido por Sustrato Peronista y 9 más

Diego A @elmonopizzero - 30 abr

\#CambiemosACambiemos \#elfracasodemacri EL MEJOR EQUIPO DE LOS

ÚLTIMOS 50años destruyendo el país.\#Vuelvecfk

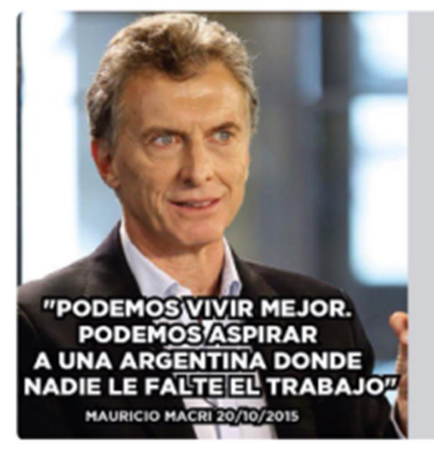

\#LoQueEICambioSeLlevó

LA INDUSTRIA

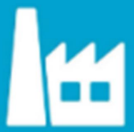

QUEBRARON

1683 EMPRESAS

FpV

Q 3 १२ 5

Demonstramos que, ao seguir o modelo de análise da circulação hipermediática contemporânea, é possível pensar na origem do caso. Assim, localizamos no discurso de origem (D1, ver figura 3) o conjunto de tweets que surgem em abril de 2017 por parte dos líderes políticos e que contém a hashtag \#ElfracasodeMacri.

Também especificamos que é central, a partir desse dispositivo analítico, atentar para a midiatização política contemporânea a fim de questionar as transformações de sentido e os movimentos comunicacionais entre as mídias em massa e as redes sociais. Deste modo, fizemos gráficos dos movimentos que a campanha teve logo depois dos enunciados públicos nas redes sociais e nos perguntamos: quais foram as mídias em massa prioritárias nesse movimento que surgiu no Twitter e que rapidamente começou a gerar discursos de oposição à presidência de Macri nas redes sociais? A princípio, é importante frisar que os movimentos repercutem nas mídias em massa no mesmo dia em que surgem nas redes sociais. 
EID\&A - Revista Eletrônica de Estudos Integrados em Discurso e Argumentação, Ilhéus, n. 16 esp."Discurso e argumentação na política latino-americana, set.2018.

Figura 3

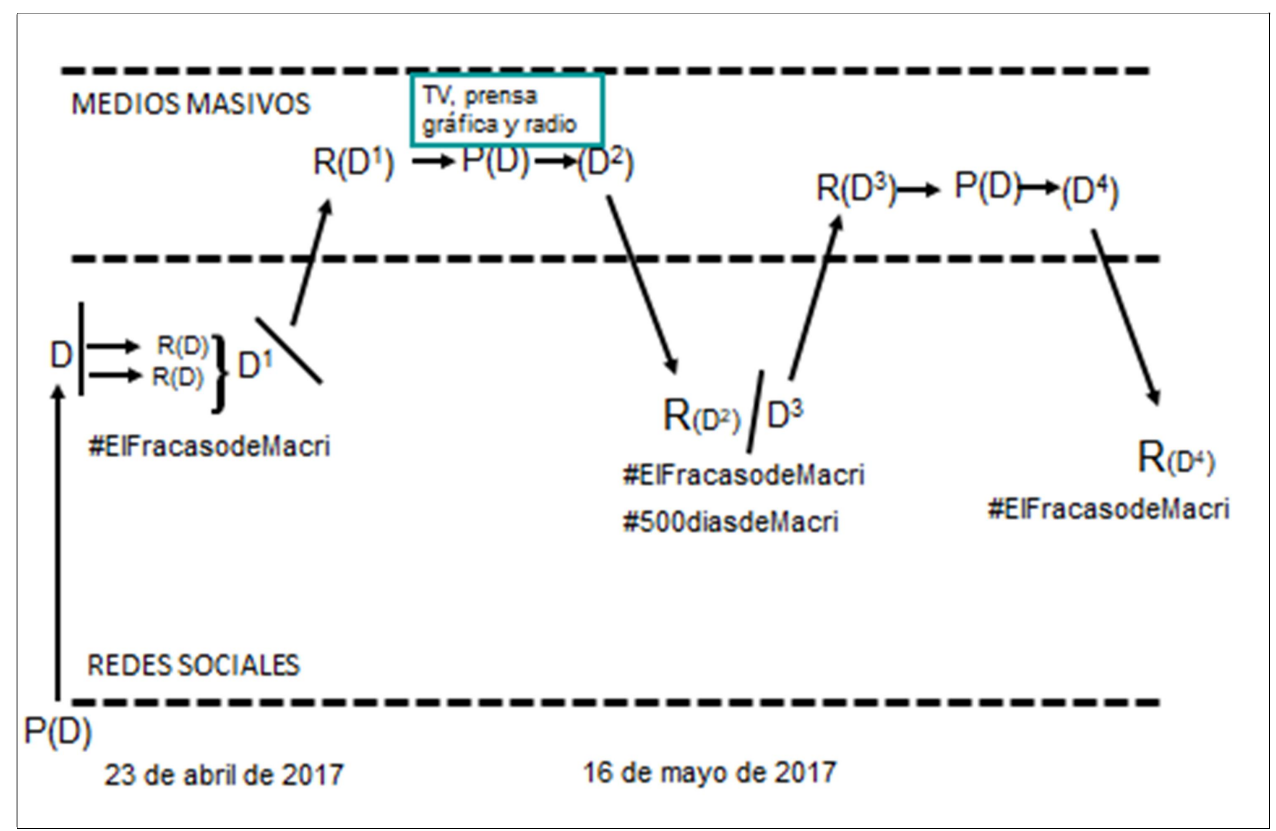

Fonte: produção própria com base no modelo da circulção hipermidiática contemporânea (CARLÓN, 2015; CARLÓN et al, 2017).

A repercussão na imprensa gráfica, televisão e rádio sinalizou pela denúncia por parte dos jornalistas de que se tratava de uma campanha feita por militantes e trolls, e que não eram internautas comuns. Na verdade, a operação concentrou-se na união da campanha de veto à gestão macrista com a força kirchnerista, e particularmente com a Cámpora. Nesse mesmo dia, o programa Economía Política (Canal $C_{5} \mathrm{~N}$ ) faz uma cobertura da campanha e do uso da hashtag no Twitter que o insere na tela (figura 4). Reproduzem-se os motivos temáticos da campanha (SERGE, 1994), ocasionando uma amplificação dos discursos de reconhecimento. Por sua vez, o jornalista Roberto Navarro realiza uma transmissão, citando os tweets, e desmente o Clarín que havia dito que a campanha era feita apenas por militantes da Cámpora. 
EID\&A - Revista Eletrônica de Estudos Integrados em Discurso e Argumentação, Ilhéus, n. 16 esp."Discurso e argumentação na política latino-americana, set.2018.

Figura 4

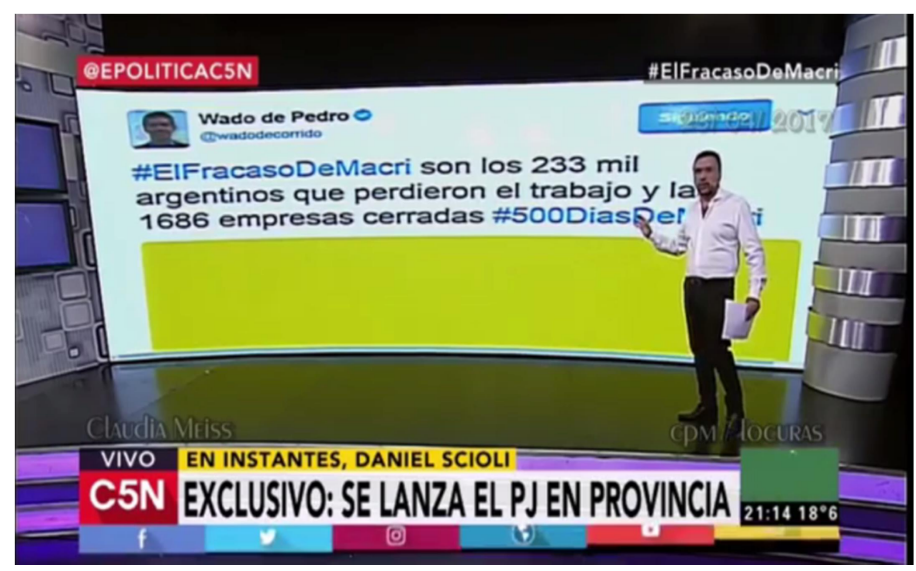

Paralelamente, em outras mídias a favor do governo macrista, o La Nación no dia seguinte nomeia em uma de suas notas: "a Cámpora se organizou para tuítar contra Macri""1. Ao todo, a esse conjunto de repercussões produzidas com as mídias em massa, designaremos de "D2" (figura 3. Gráfico 1). Após essa repercussão os discursos dos internautas anônimos aumentam e a campanha \#ElfracasodeMacri consolida-se com a articulação “50odíasdeMacri” em uma fundamental crítica à gestão macrista. O caso retorna novamente para as mídias em massa, o sentido da denúncia começa a focar mais fortemente nas mensagens anônimas, na organização dos trolls e menos no caráter institucional da campanha - nos referimos a ligação com La Cámpora - que foi a cobertura das mídias em massa realizadas no início da campanha. Nessa fase, as diferentes manchetes e transmissões televisivas mostram como a campanha continha nas redes sociais postagens repetidas por perfis diferentes, usuários bastante ativos com mensagens incongruentes, denunciando a existência de trolls. Um dos casos de maior repercussão foi a denúncia do ususário @ArezzoAraceli, que é feita por um internauta comum. Nessa conta, usando a hashtag [\#ElfracasodeMacri] relatava haver uma aposentadoria que não se alcançava com os aumentos das taxas e na foto do perfil se observava uma mulher jovem prestes a se aposentar. Muitas dessas mídias retomam a denúncia a essa conta que é feita por um internauta comum que demonstra que é um troll (figura 5). Os internautas aderem à campanha de recusa \#ElfracasodeMacri e à denúncia das

${ }^{11}$ Disponível em: http://www.lanacion.com.ar/2016137-la-campora-se-organiza-para-tuitear-contramacri 
EID\&A - Revista Eletrônica de Estudos Integrados em Discurso e Argumentação, Ilhéus, n. 16 esp."Discurso e argumentação na política latino-americana, set.2018.

contas falsas. Iniciam-se operações de apropriação por parte dos internautas comuns dos tuítes de troll para mostrar seu caráter falso (ver figuras 6 e 7).

Figura 5

\begin{tabular}{|c|c|}
\hline $\begin{array}{l}\text { Mas pobreza, la guita no alcanza. } \\
\text { Me llego0 } 1.800 \text { pesos por la } \\
\text { luz. Una locura \#EITarifazoNO } \\
\text { \#EIFracasoDeMacri } \\
12.05 \text { pM- } 16 \text { may } 17\end{array}$ & 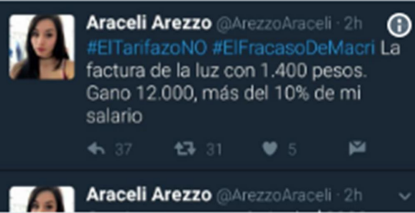 \\
\hline $\begin{array}{l}\text { Araceli Arezzo } \\
\text { Me llego } \$ 4500 \text { de gas! Tengo } \\
\text { una casa de comida! No se puede } \\
\text { seguir asi }\end{array}$ & $\begin{array}{l}\text { Gano } \$ 9000 \text { de jubilación y } \\
\text { tengo que pagar } 1100 \text { por la } \\
\text { boleta de la luz \#EITarifazoNO } \\
\text { \#EIFracasoDeMacri } \\
11007 \text { AM- } 16 \text { may } 17\end{array}$ \\
\hline
\end{tabular}

Armando Paredes.

@armandopaaredes

Hoy, el caso de la joven de 20 que gana 9000 de jubilación 12000 de sueldo, y como no le alcanza tiene una casa de comidas\#EIFracasoDeMacri

14:02 - 16 may. 2017

$\bigcirc 142 \quad \uparrow \downarrow 1.937 \quad \bigcirc 1.674$

\section{Figura 6}

- Soguido por Rarns DC

Lucía @Luchi1981.21 may

En respuesta a @MisOdios

@arezzoaraceli se likea y retweetea sus propios tweets, todos. Y nadie más, solo ella. No tengo más comentarios.

t? Araceli Arezzo Retweeted

Araceli Arezzo @ArezzoAraceli-1d

Con \#Cambiemos, llevando 2 productos

ahora pagas 3! \#MacriLaGuitaNoAlcanza

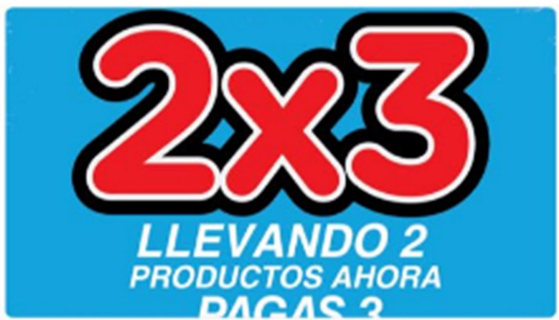

h

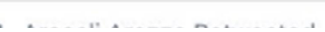


EID\&A - Revista Eletrônica de Estudos Integrados em Discurso e Argumentação, Ilhéus, n. 16 esp.“Discurso e argumentação na política latino-americana, set.2018.

Figura 7

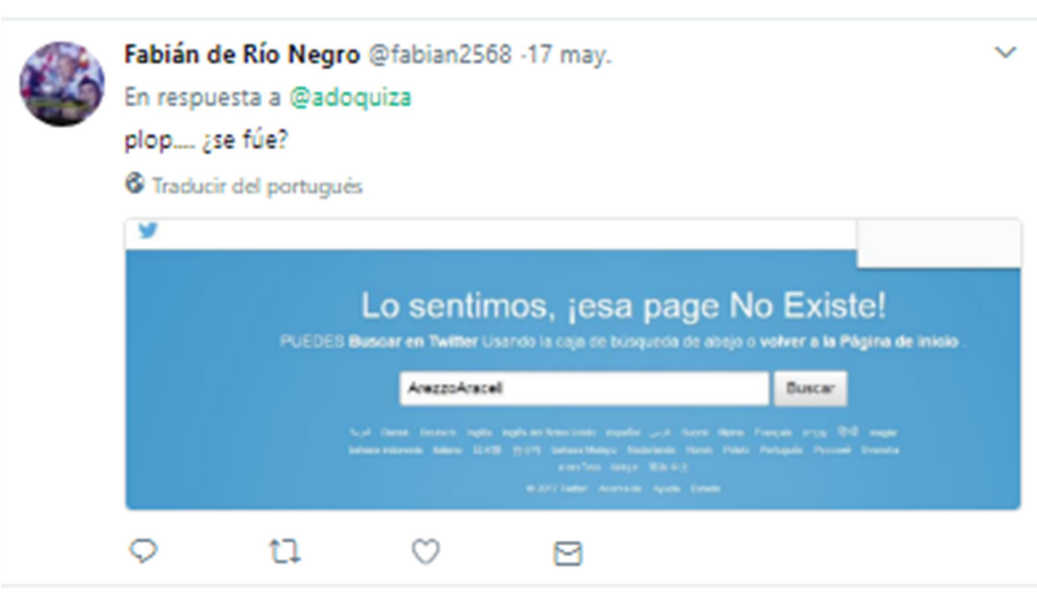

As mídias direcionam-se a mostrar que a campanha estava coordenada por robôs e mensagens automáticas. Os internautas da oposição ao governo Macrista, tanto líderes políticos como comuns, seguem participando e usando a hashtag (designadas como D3, ver a figura 3). Também são utilizadas, assim como especificamos nas redes socais de Macri, argumentações lógicas e passionais que encerram o sentido da inter-relação entre as mídias. A hashtag \#ElfracasodeMacri se juntou a \#Tuvoztuvoto e \#Asínovamosbien entre outras campanhas que criticam o macrismo. Ressurgindo no período que antecedeu as eleições primárias em agosto e as eleições gerais em outubro de 2017 e depois, com o triunfo eleitoral do Cambiemos, foi perdendo a centralidade nas redes sociais.

\section{Considerações finais}

Ao longo deste trabalho foi possível demonstrar como a emergência do político no espaço público midiatizado contemporâneo das redes sociais não implica a intermidiação dos jornalistas e seus discursos, diferente do que acontecia nas sociedades midiatizadas. Os jornalistas não são os mediadores que estabelecem o vínculo com os internautas seguidores, nem com os opositores. Ainda, nos espaços digitais de Macri no Facebook e Twitter, nas produções discursivas digitais dos líderes contrários à Macri, e nas produções dos internautas anônimos que compuseram a reação civil contra o governo macrista e se juntaram à hashtag \#ElfracasodeMacri foram registradas operações de apropriação de conteúdos e lógicas do discurso informativo. Assim, o coletivo político da oposição denuncia Macri pela operação de 
EID\&A - Revista Eletrônica de Estudos Integrados em Discurso e Argumentação, Ilhéus, n. 16 esp."Discurso e argumentação na política latino-americana, set.2018.

apropriação que é própria da meta-televisão argentina (CARLÓN, 2006): a recorrência ao arquivo televisivo para mostrar as contradições. São processos de absorção e adoção das lógicas midiáticas

Essas interfaces político-midiáticas, por um lado, estão de acordo com a quarta fase da midiatização política (STRÖMBÄCK, 2008) e com a última etapa da sociedade midiatizada (VERÓN, 1983). Porém, de outro, trata-se de operações que originam unicamente da interrelação entre os dois sistemas midiáticos e nesses pontos de intersecção entre um e outro sistema (CARLÓN, 2015). Em resumo, a criação dos coletivos políticos de internautas contém operações de emulação das lógicas próprias da era da mediatização do político nas mídias em massa, mas acrescenta outras operações produtoras de sentido político que são características das redes sociais e que cruzam várias mídias.

Ademais, nos questionamos sobre a formação do coletivo político associado à hashtag \#ElfracasodeMacri. Detalhamos que se trata de um grupo contemporâneo que emerge num movimento crescente (a partir das redes sociais), embora tenha sido gerado a partir das contas dos políticos da oposição. Analisamos as produções discursivas dos internautas públicos e anônimos que aderiram à campanha e reproduziram conteúdos nas redes com a hashtag. Especificamos que se trata de um conjunto de indivíduos unidos por um foco de interesse (VERÓN, 2013) que é o veto ao governo macrista. Examinamos que surge no Twitter devido a uma "efemeridade" (o aniversário de 500 dias da gestão de Macri) e não como produto de um acontecimento pontual de crise. Demonstramos que embora se trate de uma campanha que tem seu início pelas forças políticas organizadas, em seguida é reforçada por internautas anônimos que efetuam e endossam a mesma operação de denúncia. Indagamo-nos sobre o papel da mídia em massa e definimos que, com exceção do Economía Política da $C_{5} \mathrm{~N}$, houve replicadores das acusações feitas por internautas de que a campanha continha trolls equipados com argumentos kirchneristas. Mostramos que, ao contrário de outros movimentos sócio-políticos, nesse caso a campanha não alcança o espaço urbano. Por fim, concluímos que atualmente e logo após o início da campanha se seguem produzindo de modo esporádico mensagens no Twitter com a hashtag \#ElfracasodeMacri; entretanto, o coletivo político contrário ao governo de Macri, que contava com a militância clássica, líderes da oposição e 
EID\&A - Revista Eletrônica de Estudos Integrados em Discurso e Argumentação, Ilhéus, n. 16 esp."Discurso e argumentação na política latino-americana, set.2018.

internautas comuns está dissolvido. O curto prazo dos movimentos sóciopolíticos da era da hipermídia prevaleceu.

\section{Referências}

BRANTS, Kornelis; VOLTMER, Katrin (Eds.). Political Communication in Postmodern Democracy. Challenging the Primacy of Politics. New York: Palgrave McMillan, 2011.

CARLÓN, Mario. De lo cinematográfico a lo televisivo. Metatelevisión, lenguaje y temporalidad. Buenos Aires: La Crujía, 2006.

. Público, privado e íntimo: el caso Chicas bondi y el conflicto entre derecho a la imagen y libertad de expresión en la circulación contemporánea. In: CASTRO, P. César (Org.). Dicotomia público/privado: estamos no caminho certo? Maceió: EDUFAL, 2015. p. 211-232.

. Después del fin. Una perspectiva no antropocéntrica sobre la post-tv, el postcine y youtube. Buenos Aires: La Crujía, 2016a.

. Apropiación contemporánea de la teoría comunicacional de Eliseo Verón. In: VIZER, Eduardo; VIDALES, Carlos (Coord.). Comunicación, campo(s) teorías y problemas. Una perspectiva Internacional. Barcelona: Editorial Comunicación Social, 2016b. p. 125-153.

- Registrar, subir, comentar, compartir: prácticas fotográficas en la era contemporánea. In: CORRO, P.; ROBLES, C. (Eds.). Estética, medios y subjetividades. Santiago: Universidad Pontificia Católica de Chile, 2016c.

CARLÓN, Mario; FRATICELLI, Damion; SLIMOVICH, Ana; ROVNER, Rocio. Documento teórico-metodológico para la materia Semiótica de redes. Cátedra Mario Carlón. Facultad de Ciencias Sociales. UBA, 2017. Disponível em: http://semioticaderedescarlon.com/2016/03/13/tp-doc/

CASTELLS, Manuel. Comunicación y poder. Madrid: Alianza Editorial, 2009.

- Redes de indignación y esperanza. Los movimientos sociales en la era de internet. Madrid; Alianza Editorial, 2012.

CHERESKY, Isidoro. El nuevo rostro de la democracia. Buenos Aires: Fondo de Cultura Económica, 2015.

COULDRY, Nick. Mediatization and the future of field theory. In: LUNDBY, K. (Ed.). Mediatization of Communication. Berlin: De Gruyter Mouton, 2014. p. 227-248. 
EID\&A - Revista Eletrônica de Estudos Integrados em Discurso e Argumentação, Ilhéus, n. 16 esp.“Discurso e argumentação na política latino-americana, set.2018.

ESSER, Frank. Mediatization as a Challege: Media Logic versus Political Logic. In: KRIESI, Hanspeter et al. Democracy in the age of Globalization and Mediatization. New York: Palgrave McMillan, 2013.

FERNÁNDEZ, Mariano. Sobre la mediatización. Revisión conceptual y propuesta analítica. La Trama de la Comunicación, v. 18, 2014, p. 189-209. Disponível em: http://www.latrama.fcpolit.unr.edu.ar/index.php/trama/article/view/475/385

HJARVARD, Stig. The mediatization of Society. A Theory of the Media as Agents of Social and Cultural Change. Nordicom Review, v. 29, n. 2, 2008, p. 105-134. Disponível em: http://www.nordicom.gu.se/sites/default/files/kapitel-pdf/269_hjarvard.pdf

. A midiatizacao da cultura e da sociedad. São Leopoldo: Ed.Unisinos, 2014.

KRIESI, Hanspeter et al. Democracy in the age of Globalization and mediatization. New York: Palgrave MacMillan, 2013.

MAZZOLENI, Gianpietro; SCHULZ, Winfried. "Mediatization" of Politics: A challenge for Democracy? Political Communication, v. 16, n. 3, p.247-261, 1999.

MARCINKOWSKI, Frank. Mediatisation of Politics: reflections on the state of the concept. Javnostthe Public, v. 21, n. 2, p. 5-22, 2014.

SEGRE, Cesare. Principios de análisis del texto literario. Barcelona: Crítica, 1985.

SLIMOVICH, Ana. El Facebook de los gobernantes. El caso de Cristina Fernández de Kirchner y de Mauricio Macri. In: CARLÓN, Mario; FAUSTO NETO, Antonio. (Comp.). Las políticas de los internautas. Nuevas formas de participación. Buenos Aires: La Crujía, 2012. p. 137-154.

- El discurso macrista en Twitter: un análisis sobre la campaña para la reelección del jefe de gobierno de Buenos Aires. Revista de Estudios Políticos y Estratégicos, v. II, n. 1, 2014. Disponível em: http://vtte.utem.cl/wpcontent/themes/blogum/revista_epe/03_Rev_estudios_politicos_estrategicos_vol2_n 1_2014_Ana_S_Discurso_Macrista_8-27.pdf

. La interfaz entre lo político y lo informativo en la mediatización televisiva y las redes sociales en las campañas argentinas de 2009 y 2011. Tese (Doutorado). Facultad de Ciencias Sociales. Universidad de Buenos Aires, Buenos Aires, $2016 \mathrm{a}$.

. La digitalización de la política y la vuelta de lo televisivo. El caso de los candidatos argentinos en Facebook. Revista de Comunicación, 15, p. 111-127, 2016b. Disponível em: http://udep.edu.pe/comunicacion/rcom/pdf/2016/6_Art111-127.pdf

- Los enunciadores políticos de la protesta por el aumento de tarifas en Argentina. Un análisis hipermediático de un movimiento social contemporáneo. De Signos y Sentidos, n, 18, $2017 a$. 
EID\&A - Revista Eletrônica de Estudos Integrados em Discurso e Argumentação, Ilhéus, n. 16 esp.“Discurso e argumentação na política latino-americana, set.2018.

. La ruta digital a la presidencia argentina. Un análisis político e hipermediático de los discursos de Mauricio Macri en las redes sociales. Dixit, n. 26, p. 24-43, 2017b. Disponível

em: https://revistas.ucu.edu.uy/index.php/revistadixit/article/view/1321/1369

; TONATIUH LAY ARELLANO, Israel. La reacción ciudadana en la sociedad hipermediática contemporánea. El caso de la movilización por los estudiantes mexicanos desaparecidos de Ayotzinapa. PAAKAT: Revista de Tecnología y Sociedad, Guadalajara, 2017. Disponível em: http://www.udgvirtual.udg.mx/paakat/index.php/paakat/article/view/303

; FRATICELLI, Damián. \#NiUnaMenos. La circulación intermediática e intersistémica de un movimiento socio-político contemporáneo. In: CARLÓN, Mario. (Ed. e Comp.). La comunicación contemporánea. De las redes sociales a los medios masivos y de los medios masivos a las redes sociales. (no prelo).

STRÖMBÄCK, Jesper. Four Phases of Mediatization: An Analysis of the Mediatization of Politics. International Journal of Press/Politics, v. 13, n. 3, p. 228-246, 2008. Disponível em: http://hij.sagepub.com/content/13/3/228.short?rss=1\&ssource=mfr

; ESSER, F. Introduction: Making Sense of the Mediatization of Politics. Journalism Studies, v. 15, n. 3, 243-255, 2014.

VERÓN, Eliseo. Il est là, je le vois, il me parle. Communications, v. 38, Paris, 1983.

La mediatización. Buenos Aires: Facultad de Filosofía y Letras. Universidad de Buenos Aires, 1986.

. La semiosis social. Barcelona: Gedisa, 1987.

- Mediatización de lo político. In: GAUTHIER, Gilles; GOSSELIN, Andre; MOUCHON, Jean (Comp.). Comunicación y Política. Barcelona: Gedisa, 1998 [1995]. p. 220-236.

. El cuerpo de las imágenes. Buenos Aires, Argentina: Norma, 2001.

. La semiosis social, 2. Ideas, momentos, interpretantes. Buenos Aires: Paidós, 2013.

VOMMARO, Gabriel; MORRESI, Sérgio. Unidos y diversificados: la construcción del partido PRO en la CABA. Revista SAAP, v. 8, n. 2, p. 375-417, 2014. Disponível em: http://www.scielo.org.ar/scielo.php?script=sci_arttext\&pid=S1853-

$19702014000200002 \&$ lng=es\&tlng=es.

; ___ BELLOTI, Alejandro. Mundo PRO. Un partido fabricado para ganar. Buenos Aires, Argentina: Planeta, 2015. 
EID\&A - Revista Eletrônica de Estudos Integrados em Discurso e Argumentação, Ilhéus, n. 16 esp.“Discurso e argumentação na política latino-americana, set.2018.

Tradução:

Caio César Garcia Carniel

Mestrando do Programa de Pós-graduação em Linguística na Universidade Federal de São Carlos (UFSCar)

Vanice Maria Oliveira Sargentini

Docente do Programa de Pós-graduação em Linguística na Universidade Federal de São Carlos (UFSCar)

Forma de citação sugerida:

SLIMOVICH, Ana. A midiatização contemporânea do político: os discursos presidenciais nas redes sociais e a reação do cidadão argentino. Trad. Caio César Garcia Carniel e Vanice Maria Oliveira Sargentini. EID\&A - Revista Eletrônica de Estudos Integrados em Discurso e Argumentação, Ilhéus, n. 16 esp. "Discurso e argumentação na política latino-americana", p. 1-25, set.2018.

Recebido em: 25/07/2018

Aprovado em: 26/08/2018 